Portland State University

PDXScholar

$5-21-2021$

\title{
The Significance of Christian Iconography in Communist Mexican Muralism of Diego Rivera
}

\author{
Rachel Renee Amaro \\ Portland State University
}

Follow this and additional works at: https://pdxscholar.library.pdx.edu/honorstheses

Part of the Christianity Commons, Other History of Art, Architecture, and Archaeology Commons, and the Political Science Commons

Let us know how access to this document benefits you.

\section{Recommended Citation}

Amaro, Rachel Renee, "The Significance of Christian Iconography in Communist Mexican Muralism of Diego Rivera" (2021). University Honors Theses. Paper 1015.

https://doi.org/10.15760/honors.1042

This Thesis is brought to you for free and open access. It has been accepted for inclusion in University Honors Theses by an authorized administrator of PDXScholar. Please contact us if we can make this document more accessible: pdxscholar@pdx.edu. 
The Significance of Christian Iconography in Communist Mexican Muralism of Diego

Rivera.

\author{
by \\ Rachel Amaro \\ An undergraduate honors thesis submitted in partial fulfillment of the \\ requirements for the degree of \\ Bachelor of Arts \\ in \\ University Honors \\ and
}

Arts and Letters

Thesis Adviser

Alberto McKelligan Hernandez, PhD

Portland State University

2021 


\section{Introduction}

This study analyzes the historical and culture themes evident in Diego Rivera's murals, exploring the significance of Christian iconography in his works. From the early 1920s to almost 1940, Rivera was considered the leader of the Mexican mural Renaissance as well as one of the most famous painters in the Western World. Many scholars have focused research on Rivera's art in relation to the Mexican Revolution, specifically his art's influence by the revolution vs. its influence by government to shape the revolution. ${ }^{1}$ While many historians have broached this topic within Rivera's work, a large majority of these writings were focused on the Detroit industry murals, ${ }^{2}$ and the Rockefeller Center mural, ${ }^{3}$ as they were both largely contested due to Rivera's controversial use of communist figures and iconography. Many of Rivera's murals within Mexico have also been widely written about, but largely that of the entire mural landscape rather than focusing in on specific works within the mural.

Rivera, a self-avowed communist artist, although groundbreaking in style, relied heavily on Christian iconography throughout much of his life. Analyzing Rivera's use of Christian iconography in works done at the Palacio de Cortés in Cuernavaca México, in 1923, and the Secretaría de Educación Pública (Public Ministry of Education) building in Mexico City, Mexico in 1930, will give more insight into how the Christian culture around him heavily influenced his art and how he conveyed his message to the Christian and Catholic saturated culture surrounding him in Mexico. This analysis will deepen understandings of Rivera's artworks, exploring an aspect that art historians such as Leonard Folgarait and Pete Hamill rarely consider.

\footnotetext{
${ }^{1}$ Craven, Recent Literature on Diego Rivera and Mexican Muralism, (Latin American Research Review, 2001).

${ }^{2}$ Linda Bank Downs and Diego Rivera, Diego Rivera: The Detroit Industry Murals (New York, Detroit Institute of Arts, 1999); Anthony W. Lee, Painting on the Left (University of California Press, 1999)

${ }^{3}$ Paquette Revolutionary' Ideologies and Discursive Struggle (Orlando, Fla: The Latin Americanist, 2010)
} 


\section{Background}

Diego Rivera was born to Diego and María Barrientos Rivera in Mexico on December $8^{\text {th }}, 1886$. Rivera's father was a liberal and anticlerical, but his mother and aunt who lived with him were very religious Christians, thus Rivera was subjected to Christian imagery from childhood both in everyday life and through the art in his home. ${ }^{4}$ Rivera began to draw at the young age of six while he lived at home and the connection to his religious upbringing alongside his art journey draw a parallel to the cultural influence that undoubtably shows up in most of his works. Rivera's school experiences were in clerical schools, where he was again subjected to many Christian art works and accoutrements, as well as fine arts schools as a young boy. In 1907, his art studies took him abroad to study classical art in France and Italy where he learned the technical skills of European painting and sculpting and was influenced by French Renaissance paintings as well as many religious artists of his own time. Rivera studied in Europe until his return to Mexico in 1921. His mission while living in Europe was to replicate classical European style while staying true to his own artistic movement and his own Mexican heritage. ${ }^{5}$ What this meant for Rivera's body of work was that much of it was not only influenced, but also purposefully echoed the Christian iconography included in French and Italian Renaissance artworks.

Rivera's early life influence of European art instruction, coupled with his desire to be seen as a noteworthy artist worldwide, lead him to mimic painters such a Picasso and Bergognone in an effort to create the kind of works that would be accepted by the present

\footnotetext{
${ }^{4}$ Diego Rivera and Gladys March, My Art My Life (Dover Publications, 1991) 5. Rivera's Father worked out a truce with his family to no interfere with their religious practice in exchange they would leave Rivera alone and not take him to church or try to sway his soul toward Christianity. He was also involved with a labral veteran group that congratulated Rivera on his speech against religion.

${ }^{5}$ Rivera and March, My Art My Life, 71.
} 
bourgeoise art critics of his time. After creating his own version of Picasso's work, he was disparaged for being too different and straying too far from the acceptable form as he attempted to merge Picasso's style with that of his own as well as his Mexican heritage. ${ }^{6}$ Soon after, Rivera shifted to creating works that more resembled that of early renaissance art which also allowed for him to create his own style that included heavy influence of the Mexican culture. This evolved style is what we see in many of Rivera's well know murals and is where he repeatedly employs Christian iconographical elements.

\section{Artwork analysis}

Rivera relied heavily on Christian iconography to translate his murals into the narrative he intended. Completed just years after the armed struggles of the conflict in Mexico, the murals by Rivera were made to depict the history of the Mexican Revolution. His repeated use of Christian artistic references suggests it came quite naturally to him and strengthens the argument that Rivera's Christian cultural influence played a considerable role in his body of work. By comparing Rivera's mural work to that of other works featuring Christian Iconography, similarities can be found that highlight how Christian cultural influence played a large role in Rivera's body of work. Rivera's 1920-21 trip to Italy to study the art of the Renaissance proved pivotal in his own artistic expressions as his first-hand knowledge of Italian religious paintings is evident within many of his works. Many Christian iconographic similarities can be found.when analyzing Rivera's fresco mural Liberation of the Peon at the Secretarīa de Educación Pública

\footnotetext{
${ }^{6}$ Rivera and March, My Art My Life, 65.
} 
building in Mexico City, (Figure 1) alongside the Italian fresco Lamentations by Giotto in 1305, (Figure 3) studied by Rivera in Italy in $1921^{7}$.

One of the most written about parallel to that of Christian iconography within Rivera's fresco Liberation of the Peon is that of the body gesture of the dead man. Limp and elongated, with his arms tied above his head, crossed feet with his face turned to the sky, this gesture is largely seen in Renaissance paintings of the crucifixion. Rivera uses this illustrative gesture to create his own sense of suffering and human tragedy that imitates the scene in Giotto's Lamentations. Similarly, Rivera's lessons learned from Giotto's painting can be seen within the context of the soldiers surrounding the dead body of the peon and attending to it, much like the people surrounding the body of Christ in Giotto's Lamentations.

Further analysis of these two works shows that color holds with it a lot of significance when looked at through the lens of iconography. The use of the color white in both Rivera's and Giotto's works signify light and purity. While Giotto uses a white cloth draped around Christ and other higher male figures to signifying their level of purity, Rivera paints the revolutionists in white to signify their own level of light that they brought to the Mexican people as well as their purity of actions.

The color red is also a dominant color used in both artist's works. In an article about the use of color in iconography, Іван Стасюк writes that the color red has two meanings, one of which was often used with Christ to emphasize pure sacrifice for humanity. ${ }^{8}$ In both paintings the dead man is portrayed to have sacrificed his life for the sake of humanity. In Diego's mural a red blanket is being draped over the dead man signifying his sacrifice for the Revolution, while

\footnotetext{
${ }^{7}$ Leah Dickerman et al, Diego Rivera Murals for the Museum of Modern Art (Ney York: Museum of Modern Art, 2021) Plate 3, Liberation of the Peon.

${ }^{8}$ Іван Стасюк. Color as An Expressive Instrument of The Icon (Historical and Cultural Studies, 2015$) 94$.
} 
in Giotto's we see the color red woven throughout the image that brings an understanding of total sacrifice by Christ.

The use of haloes is a frequently used icon within Christian murals to depict that of a holy being or a saint. Giotto paints angelic-like halos atop the heads of the angels flying above as well as the people surrounding the body of Christ, indicating their level of sainthood. Rivera creates a translation of this iconic halo with the use of oversized rims on the white sombreros of the men aiding the dead man's body. This strategic use of the white sombreros was a subtle nod again to these revolutionaries' purity and saint hood status. Finally, in Rivera's mural, the draped dead man's body is posed to show the significant wounds across his back. These red stripes, likely from being whipped, are Rivera's less subtle nod to the well know stripes that are often depicted on the body of Christ in many crucifixion type paintings. Rivera's fresco has overwhelming similarities to Giotto’s Lamentations as well as many other works depicting Christ's crucifixion and create a connection between his Mexican cultural and Christian influences within his work.

Further analysis of another piece of work done by Rivera captures again the use of Christian iconography when comparing Rivera's Agrarian Leader Zapata at Palacio De Cortés in Cuernavaca Mexico, (Figure 2) to Bergognone's “Christ risen from the tomb” in 1490, (Figure 4) another piece of work likely studied by Rivera in his Italian travels in 1920-21. In Bergognone's work, Christ's garment along with his entire body is completely white, indicating his purity, cleanliness and his righteous victory of his enemy. Rivera uses the color white to evoke the same meaning within his own model of the Revolutionary leader Zapata. Dressed in all white and standing out from the dirtied white of the soldiers behind him, Rivera uses the understood iconographic meaning of white to create a reinvention of Zapata to appear, as the title 
of this fresco states, Mexico's Agrarian Leader. While Zapata was known to ride a black horse, ${ }^{9}$ Rivera uses the presence of strong white horse to further this symbol that in Christian iconography represents purity, courage and justice. The white horse in Rivera's fresco can be compared to the white and red flag in the hand of Christ in Bergognone's painting that depict in Christian iconographic symbolism that of the triumph of the crusaders in the $12^{\text {th }}$ century. Yellow, symbolizing youth, happiness, love and benevolence in Christian Iconography, is found appearing in the background of both of these pieces. Bergognone's piece depicts a yellow glow surround Christ in a beaming like fashion behind him, while a subtle gradient of yellow used in the background of Rivera's piece on the followers of Zapata's sombreros and spears. This use of yellow signifies the benevolence of the youth involved with Zapata to bring about the Mexican Revolution, and aids in creating the narrative that their fight was the good fight, much like that of Christ's.

Finally, in both images, both Christ and Zapata are standing triumphantly over what they have defeated. Bergognone's painting depicts Christ standing atop a temple, triumphant, yet still appearing in the same mild mannered and gentle persona that he is often depicted as. Rivera's fresco draws on these same mild mannered and gentle gestures often found in paintings of Christ to position Zapata as triumphant, but still meek and a humble servant to the revolution, quite contrary to the ferocious and violent image that was often referenced in drawings of the leader. Rivera seems to have been clearly drawing on the understanding of Christian iconography to recreate his interpretation of the Revolution through his frescos and translate this to a vast majority of audiences.

\footnotetext{
${ }^{9}$ Dickerman, Indych-López, Diego Rivera Murals for the Museum of Modern Art, 81.
} 
Comparison of these works shows Rivera's considerable use of Christian iconography throughout his murals and indicates that Rivera not only was aware of these references within his work, but that he did so intentionally to create a narrative for his frescos that would be widely understood.

\section{Art History}

According to historians, iconography appeared in the end of the first century ${ }^{10}$ and has been utilized in all forms of art since through the use of color, animals, halos and gestures of the figures. Fathers Gregory and St. John Damascene are quoted to have said that the icon was the Gospel for the illiterate. ${ }^{11}$ This iconography is also seen throughout history outside of Christian works of art to convey similar meanings such as Rivera's use within his murals depicting the Mexican Revolution. Within Rivera's works, Christian iconography is used as a kind of language to speak to the people reading his works to convey the historical significance of the Mexican Revolution and create a sense of unity within Mexico.

These murals done by Rivera were part of a bigger movement within Mexico in the 1920's to the 1970's. Rivera, alongside José Clemente Orozco and David Alfaro Siqueiros, known as "The Three Greats", created a series of mural paintings mainly composed of social and political messages in an attempt to unify Mexico to a post-revolutionary war government. ${ }^{12}$

In 1910, the Mexican people overthrew the longtime reign of the corrupt dictator Porfirio Díaz. Years prior to the overthrow were plagued with violence, assassinations and civil war before the country stabilized under the revolutionary party. Much of the world's understanding

\footnotetext{
${ }^{10}$ Стасюк. Color as An Expressive Instrument of The Icon, 93.

${ }^{11}$ Стасюк. Color as An Expressive Instrument of The Icon, 93.

${ }^{12}$ Alejandro Anreus, Leonard Folgarait and Robin Adèle Greeley, Mexican Muralism: A Critical History (Berkeley: University of California Press, 2012).
} 
and remembrance of the Mexican Revolution is due in large part to Diego Rivera's recreation of the revolution and telling of a time before dictatorship through his fresco murals and paintings. Rivera, along with Orozco and Siqueiros, are said to have played a large role in creating a new national identity in Mexico through their murals commissioned by the local government. ${ }^{13}$ Art historian Catha Paquette writes:

"Certainly, mural commissions awarded in Mexico during the 1920s had served ideological functions. They were an integral part of government programs for consolidation, instrumental to its efforts to unify the nation and promote particular notions about Mexican identity—essentialist constructs of Mexican race, culture, and history." 14

This discourse around these murals all asks the question, did the murals depict the Mexican Culture and its history or did these murals shape the way Mexico viewed it's culture and the history of the Revolution? I think this question can be best answered by this deeper analysis into Rivera's cultural influences and how they shaped his art.

The Religious circumstances in Mexico around the time Rivera's work was mainly that of Christian/Catholicism and Agnostic. Rivera, raised by both a Catholic mother and an agnostic father, was exposed to two ways of thinking, but inevitably leaned toward following in his father's footsteps. Rivera's heightened ability in observation allowed him to use both knowledge of Christianity and agnosticism to give a moving speech inside his mother's church that frightened many of the members and sent the priest running. ${ }^{15}$ Thus, proving that while not

\footnotetext{
${ }^{13}$ Mary Katherine Coffey, Muralism and the People, (The Communication Review, 2010)

${ }^{14}$ Catha Paquette, Revolutionary' Ideologies and Discursive Struggle, (Orlando: The Americanist, 2010).

${ }^{15}$ Rivera and March, My Art My Life, 5.
} 
following Christianity, he clearly understood the workings of it, and knew how to speak its language both in word and art.

Philosophical movements at the time of Rivera's murals were a mix between socialism, a post-revolutionary desire to help all, and communism as it was heightened in world popularity at the time and was forming in many countries across the globe. Rivera subscribed to both communist and socialist ways of thought but was himself a self-avowed communist. He was a part of the Partido Comunista de México until 1929 when he was kicked out for not subscribing to every detail of the parties' current ideology. Later, when the party shifted its stance, they recognized Rivera once again as a member in $1955 .{ }^{16}$ Rivera's adherences to that of agnostic, communist beliefs are well known based on his own profession but can also be found in his mural works that often times caused controversy between himself and those that commissioned his work.

Much of Rivera's works in the United States were commissioned by capitalists whose ideas were opposite to that of his own. The Mural done for the Rockefeller Center ${ }^{17}$ in New York City is a prime example of Rivera creating a work that went against his own desires and beliefs. With this in mind, Rivera's work commissioned by the Mexican Government is now scrutinized for its authenticity in depicting the true Mexican Revolution history. With Rivera's track record for painting that which he was paid for rather than strictly that which he believed in, the question as to whether these murals were in fact accurate, or simply paid for by the Mexican government to promote particular notions about Mexican identity ${ }^{18}$ is largely debated on within the art historian discourse.

\footnotetext{
${ }^{16}$ Rivera and March, My Art My Life, 99.

${ }^{17}$ Paquette, Revolutionary' Ideologies and Discursive Struggle 145.

${ }^{18}$ Paquette, Revolutionary' Ideologies and Discursive Struggle 146.
} 


\section{Conclusion}

Diego Rivera's art, although groundbreaking in style, relied heavily on Christian iconography that not only came from his own background of knowledge, but also enabled him to speak to the people of Mexico in a time when they relied heavily on his art to tell the story of the Mexican Revolution. Analyzing the Christian iconography displayed within Rivera's artwork gives more insight into how his surrounding culture influenced him, his art and his voice and can further lead to understanding other artists of the Mexican Revolution who employed Christian iconography and the influence of culture in their works. This analysis of the cultural influence within Rivera's murals could be performed on other artists from this specific artistic context work to support a deeper understanding of both the artist and their work, along with playing an important role in highlighting facts that may have been overlooked in past analysis. 


\section{Bibliography:}

Anreus, Alejandro, Leonard Folgarait, and Robin Adèle Greeley. Mexican muralism: A Critical History. Berkeley: University of California Press, 2012

Стасюк, Іван. “Color as an Expressive Instrument of the Icon” Historical and Cultural Studies 2, no. 1 (2015) 93-95

Craven, David. "Recent Literature on Diego Rivera and Mexican Muralism.” Latin American Research Review 36, no. 3, (2001) 221-237. JSTOR,

Dickerman, Leah. Rivera, Diego. Indych-López, Anna. Aviram, Anny. Albertson, Cynthia and Jodi Roberts. Diego Rivera: Murals for the Museum of Modern Art. New York: The Museum of Modern Art, 2011

Downs, Linda. Rivera, Diego. Diego Rivera: The Detroit Industry Murals. New York: Detroit Institute of Arts, 1999

Hamill, Pete, and Rivera, Diego. “Diego Rivera”. Harry N. Abrams, New York: 1999.

Lee, Anthony W. Painting on the Left: Diego Rivera, Radical Politics, and San Francisco's Public Murals. London: University of California Press, 1999. 
Coffey, Mary Katherine. "Muralism and the People: Culture, Popular Citizenship, and Government in Post-Revolutionary Mexico.” The Communication Review. 5, no. 1 (2010) 7-38

Oles, James. Diego Rivera, David Alfaro Siqueiros, Jose Clemente Orozco. New York: Museum of Modern Art, 2011.

Paquette, Catha. “'Revolutionary’ Ideologies and Discursive Struggle: Diego Rivera’s 1934 Mural Commission at the Palace of Fine Arts." The Latin Americanist. 54, no. 4 (2010) 143-162.

Rivera, Diego, and March, Gladys. My Art, My Life: An Autobiography. Mineola, NY: Dover Publications, 1991. 


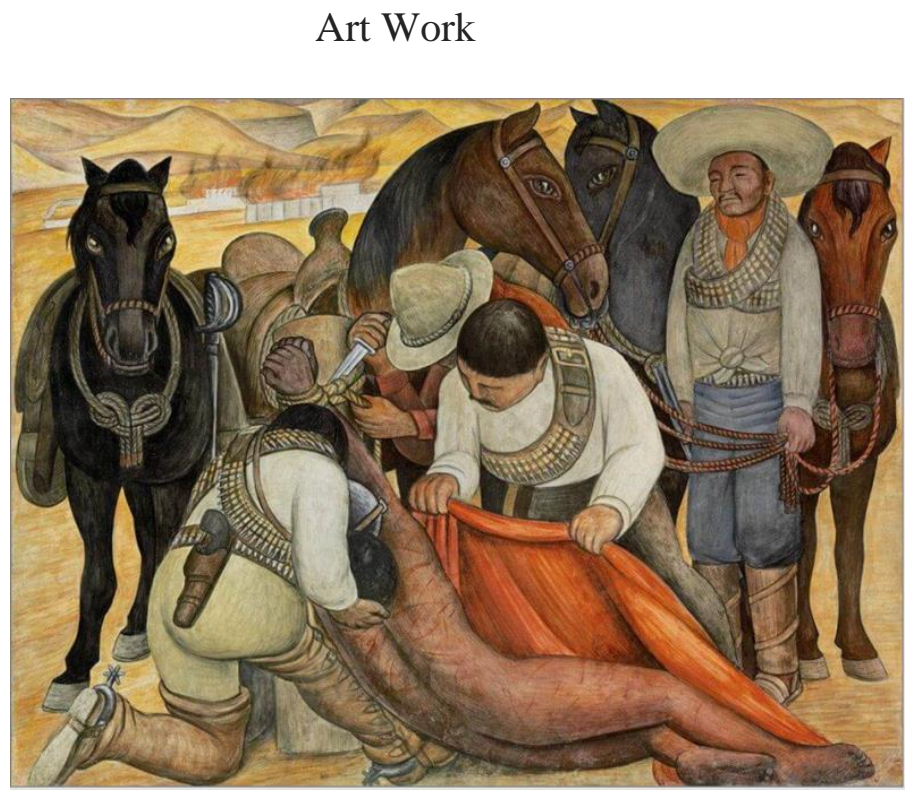

Figure 1

"Liberation of the Peon" - Diego Rivera 1923.

Secretaria De Educación Publica, Mexico City, Mexico. 


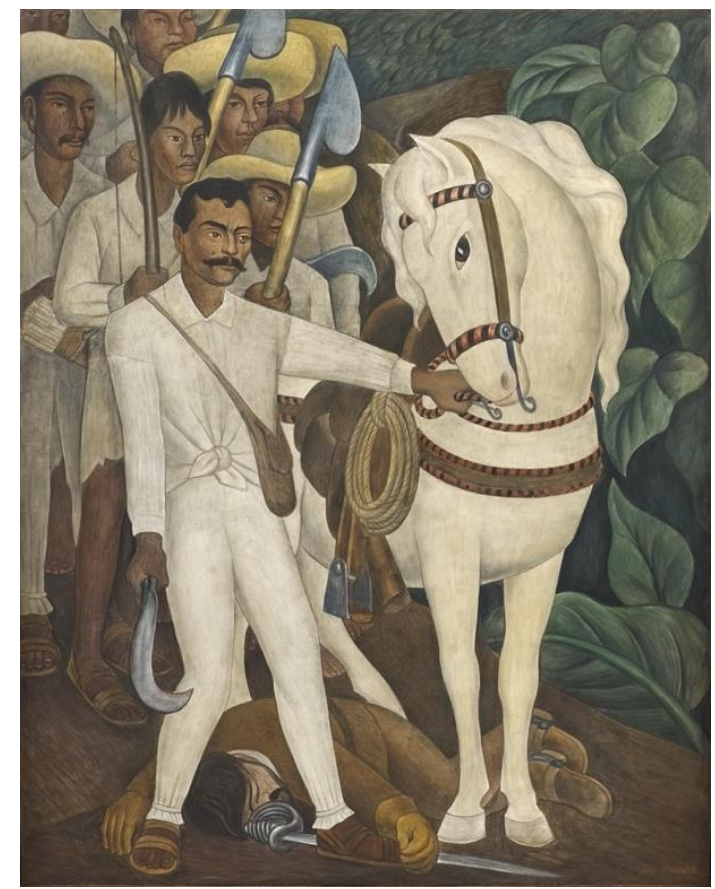

Figure 2

“Agrarian Leader Zapata” -Diego Rivera 1930

Palacio De Cortés, Mexico City, Mexico.

Comparison Art:

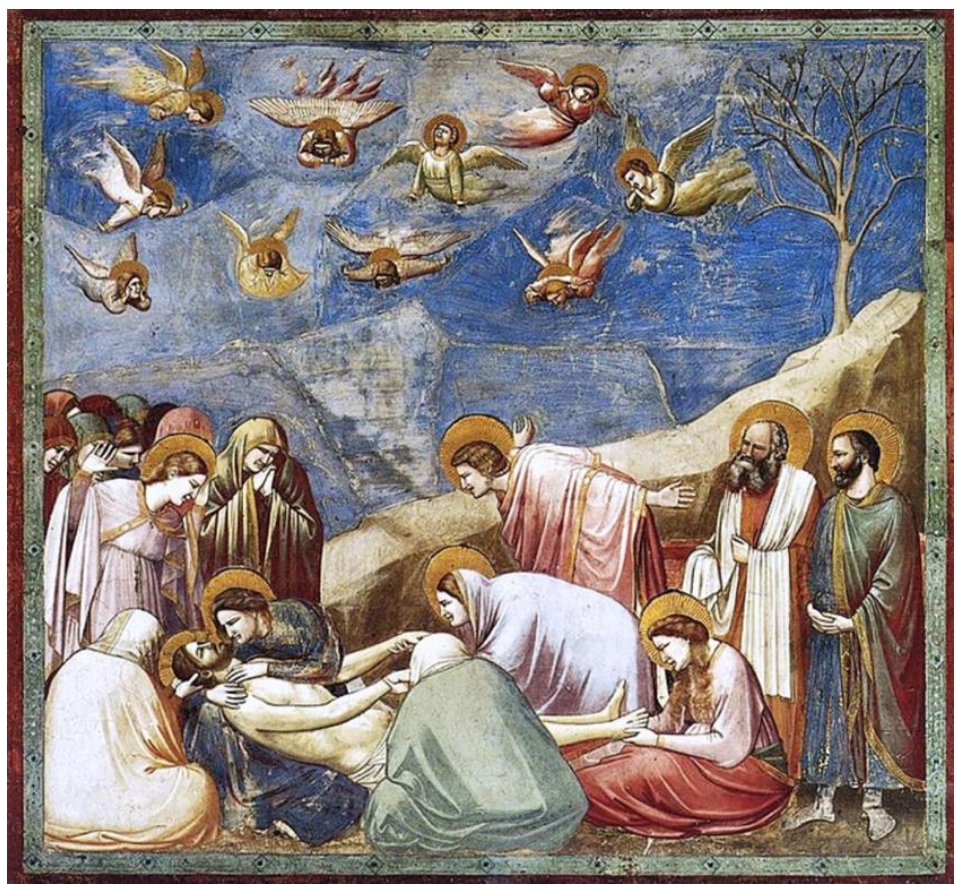

Figure 3

“Lamentations” by Giotto -1305 


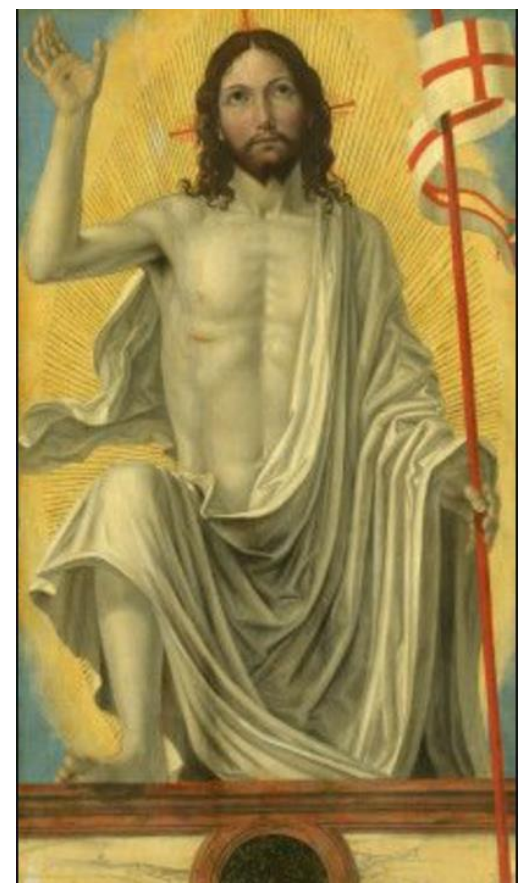

Figure 4

"Christ risen from the tomb" by Bergognone-1490 